\title{
Effects of water-depth and water-level fluctuations on the macroinvertebrate community structure in the littoral zone of Lake Constance
}

\author{
Daniel Baumgärtner · Martin Mörtl • \\ Karl-Otto Rothhaupt
}

\begin{abstract}
In a 2-year field study, abundance, biomass and community structure of benthic macroinvertebrates and their seasonal dynamics were assessed along the depth gradient in the stony littoral zone of Lake Constance, Central Europe. The macroinvertebrate community patterns differed significantly between the depth zones, partly because of species turnover, but mostly as a result of different dominance structures. These distinct differences should be considered when designing surveys of benthic invertebrates also for applied purposes, since sources of variation should be kept small and particularly on hard substrates, extensive efforts are required to obtain sufficient data for a powerful statistical analysis. A large seasonal variability in the macroinvertebrate communities of the eulittoral zone indicates a strong influence of physical disturbances, particularly of water-level fluctuations. The community pattern of the drift line samples was influenced by the previous development of the water
\end{abstract}

Guest editors: K.M. Wantzen, K. O. Rothhaupt, M. Mörtl, M. Cantonati, L.G. Tóth \& P. Fischer Ecological Effects of Water Level Fluctuations in Lakes

D. Baumgärtner

Department for Environment, Regional Council, 76247

Karlsruhe, Germany

M. Mörtl · K. O. Rothhaupt ( $ه)$

Department of Biology, Limnological Institute, University

of Konstanz, 78457 Konstanz, Germany

e mail: Karl.Rothhaupt@uni konstanz.de level. The cumulated water-level fluctuations and their net tendency accounted for three quarters of the variation in a PCA. Since Lake Constance is the only large pre-alpine lake whose water level is not extensively regulated, the uniqueness of the littoral community should have implications for nature conservation measures.

Keywords Benthos - Vertical gradient .

Ordination · Dreissena polymorpha

\section{Introduction}

The organisation of the macroinvertebrate community in the littoral zone of lakes has been subject to a number of studies since the early days of limnology. They range from commented species lists and descriptions of faunal assemblages (WesenbergLund, 1908; Muckle, 1942; Ehrenberg, 1957) to quantitative studies involving productivity (Hayne \& Ball, 1956) and effects of habitat variables and biotic interactions on the invertebrate community (Macan, 1966; Gilinsky, 1984; Diehl, 1992; Cobb \& Watzin, 1998).

However, the relative importance of biotic and abiotic processes in the structuring of macroinvertebrate communities of littoral habitats is largely unknown (Johnson \& Goedkoop, 2002). Compared to the large research effort in studying the water 
column of lakes or the benthos of streams, relatively little is known about the stony littoral zone of lakes (Harrison \& Hildrew, 1998a). Part of the difficulty arises in the large variation in replicate samples. Extensive efforts are required to obtain sufficient statistical data to detect changes in the fauna. Spatial heterogeneity in the littoral zone, the patchy distribution of benthic organisms and sampling bias overlap with potential impacts of changes in the environment or experimental perturbations. It is therefore crucial to optimise sampling precision and to take into account other sources of variation. In field studies of the impact of single factors and mechanisms, it is necessary to consider habitat gradients and seasonal changes in the community since they add to the "noise" of the data structure by overlapping with the biological signal if their impacts are not known or not considered (Reid et al., 1995; Johnson, 1998).

The presence or absence of organisms in a lake might depend on large-scale factors, such as climate, geology, or colonisation history (Johnson \& Goedkoop, 2002). Comparisons of fauna of the littoral zones of lakes have pointed to the importance of environmental variables. Lake morphometry, productivity and water chemistry (Jackson \& Harvey, 1993; Bailey et al., 1995), and biotic factors, e.g. the presence of fish and the extent of predation exerted on the macroinvertebrate community have proven to be good predictors in comparisons of invertebrate communities among lakes (Jackson \& Harvey, 1993; Wong et al., 1998).

Within a lake, biotic factors, such as predator prey interactions, competition and life-history traits, play a major role for the community structure (e.g. Gilinsky, 1984; Johnson et al., 1996; Harrison \& Hildrew, 1998b, 2001).

However, the importance of single factors in the interplay of biological interactions and physical characteristics for the benthic community is not yet clear. Particularly in the littoral zone of large lakes, a multitude of abiotic gradients can influence biotic interactions differently depending on water depth: Hydraulic stress on organisms caused by wave action is lower in deeper water. Habitat stability, substrate particle size and with that the availability of shelter for macroinvertebrates change with water depth. Radiation attenuates and the light spectrum becomes narrower with depth, and the epilithic algal community a food resource for grazers is altered. Temperature and daily temperature ranges vary depending on water depth, season and with the degree of internal seiches (Dall et al., 1984; Winnell \& Jude, 1987; Death, 1995; Tolonen et al., 2001).

Fluctuations in water level do not only provide additional dynamics in the littoral zone, e.g. by limiting the temporal scale of succession in the upper littoral zone or by determining the available settlement area, but they also shift the locations of vertical gradients and affect their quality.

The aim of this study was to explore changes in the macroinvertebrate community structure along a vertical habitat gradient. We did not include other possible abiotic parameters or biotic interactions in order to keep the model simple and to focus on the influence of water depth (and correlated factors) and of water-level fluctuations on the macroinvertebrate community in the stony littoral zone of Lake Constance.

\section{Methods}

Study area

Upper Lake Constance $\left(47^{\circ} 39^{\prime} \mathrm{N}, 9^{\circ} 18^{\prime} \mathrm{E}\right)$ is a large pre-alpine lake $\left(500 \mathrm{~km}^{2}\right)$ in Central Europe with a maximum depth of $254 \mathrm{~m}$. At mean water level, about $12 \%\left(57 \mathrm{~km}^{2}\right)$ of the lake's total area is shallow water less than $10 \mathrm{~m}$ deep and is therefore classified as the littoral zone (IGKB, 1994). The average waterlevel fluctuation is about $2 \mathrm{~m}$ annually, with a minimum in February and a maximum in the summer, triggered by melting water runoff in the Alps (Fig. 1).

The sampling was conducted on the southwestern shore of the Überlingen Basin, a part of Upper Lake Constance, on a leeward erosion bank with a wide boulder shore. The littoral sediment there consists mainly of silty sands with a loosely packed stony overlay, a habitat that occurs frequently in the littoral zone of Lake Constance (Fischer \& Eckmann, 1997).

Sampling design

Starting in September 1999, benthic invertebrates were sampled every 3 months over a period of 


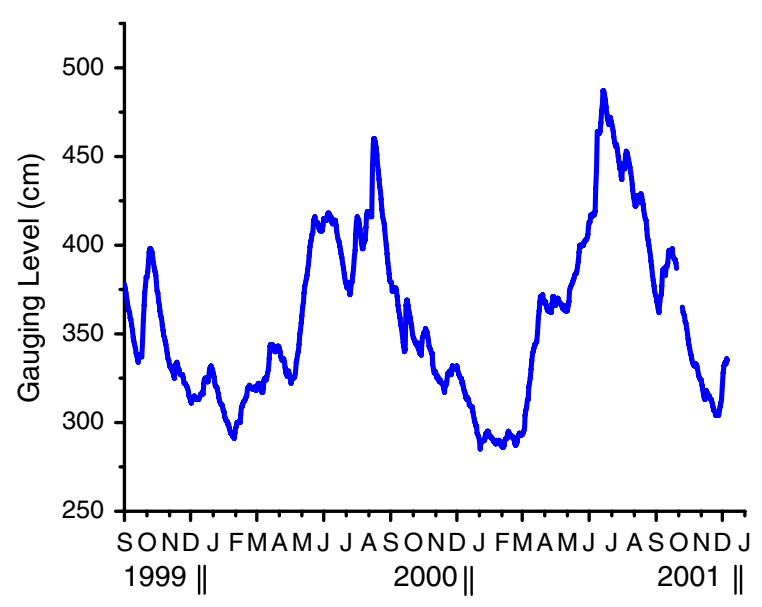

Fig. 1 Course of the gauging level of Lake Constance, station Constance Harbour. Long term average low water level: $262 \mathrm{~cm}$. Gap: no data available

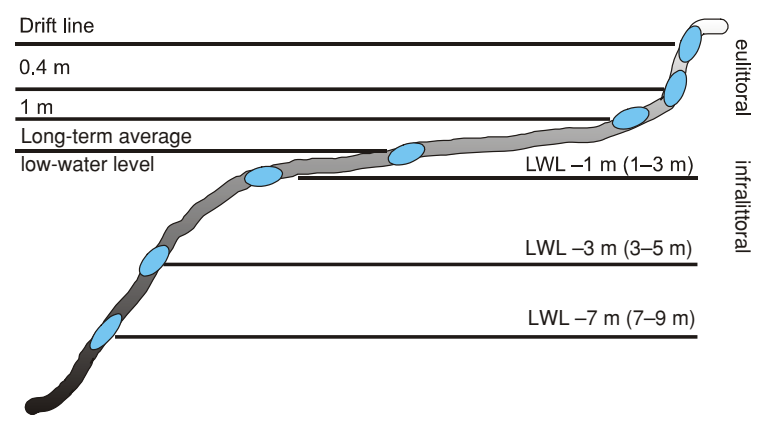

Fig. 2 Vertical zonation of sampling stations

2 years from up to 7 depths; the number of depth zones sampled depended on the water level (Fig. 2). Sampling dates were September 23, 1999, December 14, 1999, March 14, 2000, June 20, 2000, September 29, 2000, December 18, 2000, March 20, 2001 and June 26, 2001. To observe temporal changes on a monthly basis, an additional sampling was carried out on April 12, 2000.

Five replicates from each depth zone were taken randomly in a shoreline of $3050 \mathrm{~m}$, three of which were counted. Four fixed depth zones were sampled: the zone of the average low-water level (LWL), which is equivalent to a gauging level of $262 \mathrm{~cm}$ measured at Constance harbour; and three infralittoral depths, 1, 3 and $7 \mathrm{~m}$ below the $\operatorname{LWL}(-1,-3$, and $-7 \mathrm{~m}$ ). At these zones, water depth changed according to the water level.

In the eulittoral zone, up to three shifting depths were sampled; the water depth was invariable, but the location depended on the water level: the drift line (surf zone), $0.4 \mathrm{~m}$ and $1 \mathrm{~m}$ water depth. Shifting sampling depths in the eulittoral zone were chosen since the actual water depth should have a considerable influence on the macroinvertebrate community and should therefore be kept fixed. The eulittoral sampling depth in $1 \mathrm{~m}$ water depth was only present in the June samples when the water level was high.

To see whether colonisation from the interstitial was possible during the rising water level in summer, a quantitative interstitial sampling was carried out on March 18, 2001, by sampling a defined area $\left(25 \times 25 \mathrm{~cm}^{2}\right)$ at a distance of 3,5 and $7.5 \mathrm{~m}$ from the drift line. These sampling locations had been dry for at least the previous 24 weeks.

\section{Sampling devices}

For benthos sampling, two different suction samplers were used. The eulittoral zone down to the average LWL was sampled using the Eulittoral Suction Sampler (ESS) with a sampling area of $30 \times 40 \mathrm{~cm}^{2}$; the infralittoral zone was sampled using the Infralittoral suction Sampler (ISS, sampling area $25 \times 25 \mathrm{~cm}^{2}$ ) and SCUBA diving. A detailed description of these samplers and a comparison of their sampling precision and accuracy are given in Baumgärtner (2004). Driftline invertebrates were sampled with a frame $\left(25 \times 25 \mathrm{~cm}^{2}\right)$ and a hand net. Mesh size was always $200 \mu \mathrm{m}$.

\section{Sorting and sieving}

The benthos samples were brought to a climate chamber $\left(4^{\circ} \mathrm{C}\right)$ on the same day and processed in the laboratory on the same or next day. Stones were rinsed and brushed gently to remove all organisms. Fine sediments were stirred up repeatedly, and the floating organisms and debris were collected on a 200- $\mu \mathrm{m}$ sieve. The remaining sediments were sorted by hand and searched for dense animals such as molluscs and caddisflies. Each sample was then preserved in $70 \%$ ethanol.

\section{Biomass estimation}

Invertebrate biomass was estimated using length dry mass regressions (Baumgärtner \& Rothhaupt, 2003). Each taxon was grouped into three size classes. For 
each taxon, the sampling date was recorded and size class and body length parameters of 1020 individuals were determined. From the median of each size class, the average dry mass was determined, and the population biomass was calculated by extrapolating the weighted means of these size classes. Average dry mass values were used for several taxa for which body size measurements are not useful, such as hydrozoa, oligochaeta and hirudinea. For molluscs and caddisfly larvae, dry mass was calculated for the soft body without shells or cases.

\section{Statistical analyses}

Multivariate community measures were used to include information on the occurrence, abundance and biomass of as many taxa as possible in the evaluation, while at the same time to reduce the complexity of the data. For the graphic representation of community relationships, non-metric multidimensional scaling (NMDS) was applied (Kruskal \& Wish, 1978). NMDS is an iterative ordination method and uses the ranks of similarities between samples for a low-dimensional ordination. In contrast to the analogous principle component analyses (PCA), the underlying similarity matrix can be chosen freely and is not restricted to Euclidean distances. This is an advantage in the evaluation of community data, because the nature of species-sample matrices with a high prevalence of zero entries causes major problems in fulfilling assumptions for parametric statistics, such as normal distribution of data. The use of ranks between samples for the ordination makes it clear that the distances in an NMDS plot are relative. Relative distances in a plot reflect the relative dissimilarity between samples. NMDS plots can be arbitrarily rotated, scaled etc. and do not posses defined axes.

For computing similarity between samples, the Bray-Curtis coefficient was used. An important advantage of the Bray-Curtis coefficient is that it is not influenced by joint absences of species in two samples, a condition that many other coefficients fail (Clarke \& Green, 1988).

Similarity was measured on matrices with absolute numbers of biomass and abundance per $\mathrm{m}^{2}$. To balance the contribution of common and rare species, the biomass and abundance data were square-root transformed prior to calculating sample similarities.
The reliability of the two-dimensional picture of the multidimensional relationship between the samples is indicated by a stress value (Kruskal \& Wish, 1978). Stress values $<0.05$ give excellent representation without the prospect of misinterpretation (Clarke, 1993), stress values $<0.1$ correspond to a good representation of the similarities between the samples and stress values $>0.2$ indicate that not too much reliance should be placed on details. However, this is a simplified guideline since, for example, stress tends to increase with increasing sample numbers. All NMDS plots in this study were produced with PRIMER 5.0, and the algorithm was restarted ten times for each plot.

Similarities between the drift line samples and other depth zones were analysed with the ANOSIM procedure in PRIMER (Clarke \& Green, 1988), which compares the ranked similarities for differences within and between previously defined groups. This test is somewhat comparable to ANOVA/MANOVA, but, like NMDS, it makes few, if any, assumptions on data and is calculated by permutation applied to the underlying similarity matrix. While the resulting $R$-values in theory lie within the range of -1 to $+1, R$ is approximately 0 if the null hypothesis is true, and it usually lies between 0 and 1 (but see Chapman \& Underwood, 1999). $R$-values close to 1 indicate separation of the groups; values close to 0 imply little or no segregation. For the ANOSIM tests in this study, the same matrices as for the NMDS plots with square-root transformed data and Bray-Curtis similarity were used.

The contribution of species to average dissimilarity between the depth zones was elucidated using the SIMPER routine in PRIMER (Clarke, 1993). The Bray-Curtis similarities between samples were disaggregated by computing average dissimilarities between all pairs of inter-group samples and then breaking down this average into separate contributions from each species to dissimilarity.

The ratio of the average dissimilarity and standard deviation is given as a measure of how consistent the species contributes to the characterisation of differences between groups. We focused on differences between the drift line samples $(0 \mathrm{~m})$ and LWL and infralittoral (LWL $-7 \mathrm{~m}$ ), respectively.

Correlations between water-level fluctuations and macroinvertebrate drift-line samples were assessed 
with the BIO-ENV routine in PRIMER (Clarke \& Ainsworth, 1993). This procedure is an exploratory tool for species environment relationships, using separate similarity or dissimilarity matrices for biological and environmental data. First, a correlationbased PCA on abiotic variables was calculated: water-level fluctuations of the previous 3, 7, 14 and 28 days, their net tendency (sinking or rising water level), and the number of days on which the drift line had been flooded were included (Fig. 7). In the BIO-ENV routine, similarity matrices with subsets of these abiotic variables, based on Euclidean distance, were then compared with the Bray-Curtis similarity matrices of square-root transformed abundance and biomass data of the drift line samples, maximising rank correlations expressed as weighted Spearman rank correlation $\rho$.

\section{Results}

\section{Community patterns}

In 173 benthic samples, 48 taxa were distinguished. A total of 27 taxa occurred in more than half of all samples. In general, the ordination of samples by NMDS revealed similar patterns for abundance and biomass (Figs. 3 and 4). The largest space in the plot is occupied by the drift-line samples, which are responsible for the most pronounced differences.

The ordination of the highly variable drift-line samples was estimated separately (Figs. 5 and 6) and correlated with water-level variables. The ordination of samples according to fluctuations in the water level by PCA is shown in Fig. 7. PC axis 1 is mainly

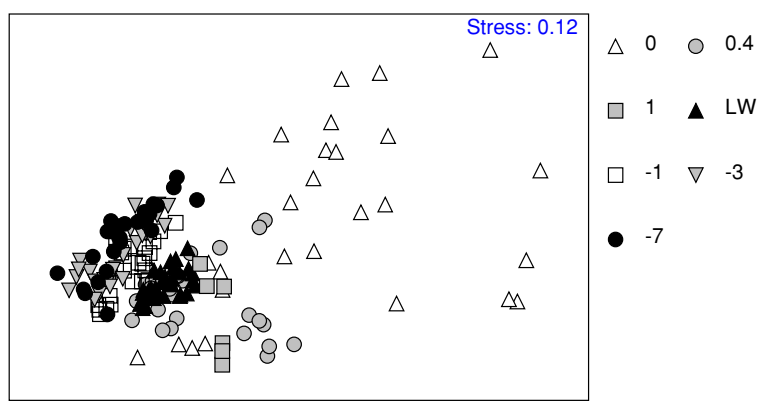

Fig. 3 NMDS plot of invertebrate abundance, including drift line samples, grouped over depth zones $(\mathrm{m})$. The data were square root transformed. LW: low water level

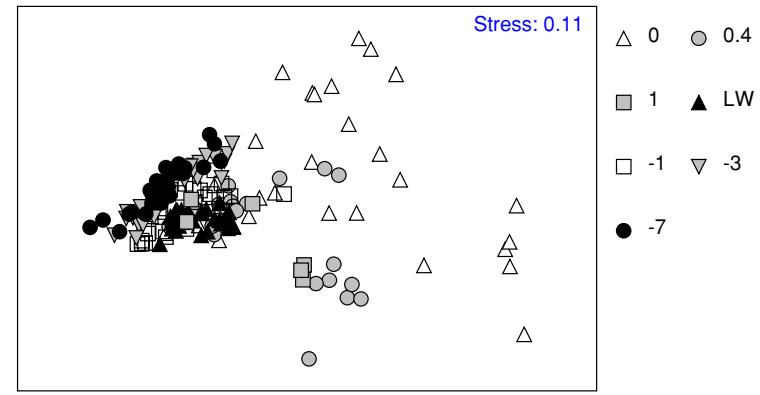

Fig. 4 NMDS plot of invertebrate biomass including drift line samples, grouped over depth zones $(\mathrm{m})$. The data were square root transformed. LW: low water level

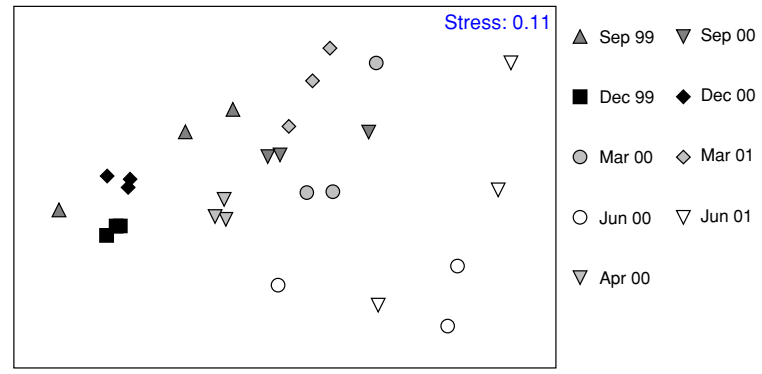

Fig. 5 NMDS plot on invertebrate abundance of drift line samples, grouped over sampling dates. The data were square root transformed

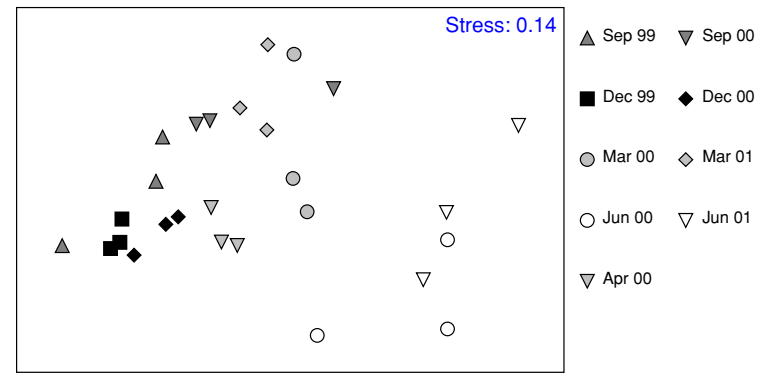

Fig. 6 NMDS plot on invertebrate biomass of drift line samples, grouped over sampling dates. The data were square root transformed

influenced by absolute cumulated water-level fluctuations prior to the sampling, with positive values representing small fluctuations and negative values representing larger variation, while axis 2 represents the net tendency of the water level, with negative values indicating rising water level (Table 1). The single variable that grouped the drift-line samples best, in a manner consistent with the faunal patterns based on biomass, was the cumulated water-level fluctuation of the previous 3 days (BIO-ENV, 


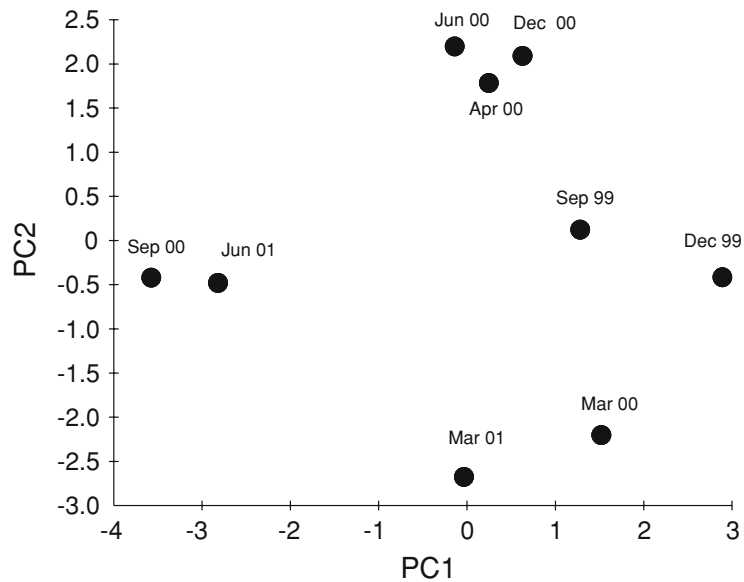

Fig. 7 PCA ordination of the sampling dates based on gauging level variables

weighted Spearman rank correlation $\rho=0.53$ ). Considering ordination by abundance, a combination of four factors delivered the best correlation: the number of days that the drift line had been flooded, the cumulated water-level fluctuations 3 and 28 days prior to the sampling and the net tendency of the previous 2 weeks (BIO-ENV, weighted Spearman rank correlation $\rho=0.51$ ).

Differences in multivariate community structure between depth zones were tested with ANOSIM tests on abundance and biomass. Global differences were significant for abundance and biomass between depth
Table 2 ANOSIM test for differences in abundance or bio mass between surf zone samples and other depth groups (averaged across all month groups)

\begin{tabular}{llrllr}
\hline Test & \multicolumn{2}{l}{ Abundance } & & \multicolumn{2}{l}{ Biomass } \\
\cline { 2 - 3 } & $R$ & & & $R$ & \multicolumn{1}{l}{$P$} \\
\hline Global & $\mathbf{0 . 6 3 2}$ & $<0.001$ & & $\mathbf{0 . 5 8 1}$ & $<0.001$ \\
0, 0.4 & $\mathbf{0 . 7 7 4}$ & $<0.001$ & & $\mathbf{0 . 6 6 5}$ & $<0.001$ \\
0, 1 & $\mathbf{0 . 9 2 6}$ & 0.002 & $\mathbf{0 . 9 3 3}$ & 0.002 \\
0, LWL & $\mathbf{0 . 8 9 5}$ & $<0.001$ & $\mathbf{0 . 8 8 5}$ & $<0.001$ \\
0, 1 & $\mathbf{0 . 9 1 2}$ & $<0.001$ & & $\mathbf{0 . 8 8 9}$ & $<0.001$ \\
$0, \quad 3$ & $\mathbf{0 . 9 4 5}$ & $<0.001$ & $\mathbf{0 . 9 1 3}$ & $<0.001$ \\
$0, \quad 7$ & $\mathbf{0 . 8 9 6}$ & $<0.001$ & $\mathbf{0 . 8 8 7}$ & $<0.001$ \\
\hline
\end{tabular}

Pronounced differences are in bold. LWL: low water level

zones (Table 2). As seen in the NMDS plot, drift-line samples proved to be very different from all other samples, with $R>0.88$ except for the 0.4-m samples, where the difference is somewhat smaller, but still pronounced $(R=0.77$ for abundance and 0.67 for biomass).

\section{Species analyses}

The dominant species Dreissena polymorpha contributed most to the differences between the examined depth groups $(0, \mathrm{LWL},-7 \mathrm{~m})$ with regard to abundance (Table 3) and biomass (Table 4); the latter was more pronounced. The zonation of the chironomid subfamilies also accounts for a

Table 1 PCA on gauging level variables

\begin{tabular}{|c|c|c|c|c|c|}
\hline & PC 1 & PC 2 & PC 3 & PC 4 & PC 5 \\
\hline Eigenvalues & 3.87 & 2.88 & 1.18 & 0.70 & 0.22 \\
\hline$\%$ Variation & 43 & 32 & 13.1 & 7.8 & 2.5 \\
\hline$\%$ Cumulated variation & 43 & 75 & 88.1 & 95.9 & 98.4 \\
\hline \multicolumn{6}{|l|}{ Eigenvectors } \\
\hline Number of days flooded & 0.358 & 0.285 & 0.061 & 0.575 & 0.047 \\
\hline 3 Day fluctuation & 0.339 & 0.285 & 0.427 & 0.044 & 0.671 \\
\hline 3 Day tendency & 0.333 & 0.409 & 0.029 & 0.259 & 0.096 \\
\hline 7 Day fluctuation & 0.463 & 0.088 & 0.316 & 0.179 & 0.031 \\
\hline 7 Day tendency & 0.047 & 0.452 & 0.491 & 0.245 & 0.510 \\
\hline 14 Day fluctuation & 0.435 & 0.210 & 0.233 & 0.288 & 0.221 \\
\hline 14 Day tendency & 0.167 & 0.447 & 0.398 & 0.396 & 0.286 \\
\hline 28 Day fluctuation & 0.453 & 0.128 & 0.165 & 0.400 & 0.059 \\
\hline 28 Day tendency & 0.083 & 0.446 & 0.482 & 0.330 & 0.378 \\
\hline
\end{tabular}


Table 3 Results of the SIMPER routine: contribution of taxa to average dissimilarities between depth zones based on abundances

\begin{tabular}{|c|c|c|c|c|c|c|}
\hline \multirow[t]{2}{*}{ Species } & \multicolumn{2}{|c|}{$\begin{array}{l}\text { Average abundance } \\
\text { (ind. } \mathrm{m}^{-2} \text { ) }\end{array}$} & \multirow[t]{2}{*}{$\begin{array}{l}\text { Average } \\
\text { dissimilarity }\end{array}$} & \multirow[t]{2}{*}{ Dissimilarity/SD } & \multirow[t]{2}{*}{$\begin{array}{l}\text { Species } \\
\text { contribution }(\%)\end{array}$} & \multirow[t]{2}{*}{ Cumulative (\%) } \\
\hline & Group 1 & Group 2 & & & & \\
\hline \multicolumn{7}{|l|}{ Groups 0 and LWL } \\
\hline \multicolumn{7}{|l|}{ Average dissimilarity $\quad 67.64$} \\
\hline Dreissena polymorpha & 6676.2 & 8415.8 & 8.96 & 1.76 & 13.25 & 13.25 \\
\hline Chironominae & 978.4 & 6221.0 & 7.81 & 2.00 & 11.54 & 24.79 \\
\hline Caenis spp. & 122.2 & 4273.0 & 6.92 & 1.95 & 10.23 & 35.02 \\
\hline Tinodes waeneri & 39.1 & 2277.1 & 5.45 & 1.77 & 8.06 & 43.08 \\
\hline Tanypodinae & 41.5 & 1322.0 & 4.11 & 2.85 & 6.08 & 49.16 \\
\hline Oligochaeta & 422.5 & 1288.1 & 3.25 & 1.51 & 4.81 & 53.96 \\
\hline Centroptilum luteolum & 0.6 & 610.2 & 3.02 & 2.86 & 4.46 & 58.42 \\
\hline Orthocladiinae & 2055.7 & 1317.4 & 2.95 & 1.36 & 4.36 & 62.78 \\
\hline Pisidium spp. & 30.8 & 362.6 & 1.89 & 1.86 & 2.80 & 65.58 \\
\hline Polycentropus flavomaculatus & 12.4 & 278.2 & 1.86 & 2.10 & 2.76 & 68.34 \\
\hline Bithynia tentaculata & 30.2 & 286.3 & 1.64 & 1.38 & 2.43 & 70.77 \\
\hline Gammarus roeseli & 218.1 & 384.7 & 1.63 & 1.34 & 2.41 & 73.18 \\
\hline Hydroptila sp. & 33.2 & 226.9 & 1.47 & 1.36 & 2.18 & 75.36 \\
\hline \multicolumn{7}{|l|}{ Groups 0 and 7} \\
\hline \multicolumn{7}{|l|}{ Average dissimilarity $\quad 71.37$} \\
\hline Dreissena polymorpha & 6676.2 & 18778.7 & 13.55 & 1.42 & 18.98 & 18.98 \\
\hline Chironominae & 978.4 & 4867.0 & 7.85 & 1.65 & 11.00 & 29.98 \\
\hline Oligochaeta & 422.5 & 2564.2 & 5.22 & 1.32 & 7.31 & 37.29 \\
\hline Pisidium spp. & 30.8 & 1588.7 & 5.14 & 2.35 & 7.20 & 44.50 \\
\hline Tanypodinae & 41.5 & 1536.6 & 4.94 & 1.96 & 6.92 & 51.42 \\
\hline Caenis spp. & 122.1 & 1775.4 & 4.46 & 1.56 & 6.25 & 57.66 \\
\hline Orthocladiinae & 2055.7 & 89.5 & 4.12 & 1.25 & 5.78 & 63.44 \\
\hline Potamopyrgus antipodarum & 1.2 & 730.7 & 3.29 & 1.60 & 4.61 & 68.05 \\
\hline Acari & 1.2 & 557.6 & 3.08 & 1.73 & 4.31 & 72.37 \\
\hline Mystacides azurea & 7.1 & 235.9 & 2.01 & 2.22 & 2.82 & 75.19 \\
\hline
\end{tabular}

Cut off at $75 \%$. SD: standard deviation; LWL: low water level

considerable part of the differences: In drift-line samples, Chironominae and Tanypodinae occurred rarely, while Orthocladiinae reached highest abundances there. With regard to abundance, the Tanypodinae were a good taxon for discriminating between the depth zones examined: the relatively high ratio between dissimilarity and standard deviation of approximately 2 indicated a frequent contribution to differences in comparisons of samples between depth groups. Other good discriminators between the drift line and the LWL with regard to abundance and biomass were the mayflies Caenis spp. and Centroptilum luteolum and the caseless caddisfly larvae Polycentropus flavomaculatus and Tinodes waeneri.

Larvae of the mayfly Ecdyonurus dispar and of the stonefly Leuctra sp. occurred only in the eulittoral samples in June at high water level, but not in any other of the lake bottom samples. However, in the interstitial sampling in March 2001, we found early instars of Ecdyonurus dispar and Leuctra sp. larvae inhabiting the upper centimetres of the dry eulittoral zone in abundances of $96( \pm 16)$ ind. $/ \mathrm{m}^{2}$ and 1328 $( \pm 961)$ ind. $/ \mathrm{m}^{2}$, respectively (mean $\pm \mathrm{SE}$ ). 
Table 4 Results of the SIMPER routine: contribution of taxa to average dissimilarities between depth zones based on biomass

\begin{tabular}{|c|c|c|c|c|c|c|}
\hline \multirow[t]{2}{*}{ Species } & \multicolumn{2}{|c|}{ Average biomass $\left(\mathrm{mg} \mathrm{m}^{-2}\right)$} & \multirow{2}{*}{$\begin{array}{l}\text { Average } \\
\text { dissimilarity }\end{array}$} & \multirow{2}{*}{$\begin{array}{l}\text { Dissimilarity/ } \\
\text { SD }\end{array}$} & \multirow{2}{*}{$\begin{array}{l}\text { Species } \\
\text { contribution }(\%)\end{array}$} & \multirow{2}{*}{$\begin{array}{l}\text { Cumulative } \\
(\%)\end{array}$} \\
\hline & Group 1 & Group 2 & & & & \\
\hline \multicolumn{7}{|l|}{ Groups 0 and LWL } \\
\hline \multicolumn{7}{|l|}{ Average dissimilarity $\quad 70.26$} \\
\hline Dreissena polymorpha & 5928.2 & 38247.2 & 25.97 & 1.99 & 36.96 & 36.96 \\
\hline Tinodes waeneri & 5.3 & 527.6 & 3.94 & 2.32 & 5.61 & 42.57 \\
\hline Chironominae & 43.4 & 578.1 & 3.58 & 2.17 & 5.09 & 47.67 \\
\hline Bithynia tentaculata & 137.6 & 640.6 & 3.45 & 1.62 & 4.91 & 52.58 \\
\hline Centroptilum luteolum & 0.1 & 326.1 & 3.05 & 2.00 & 4.34 & 56.92 \\
\hline Gammarus roeseli & 416.1 & 589.5 & 2.96 & 1.54 & 4.22 & 61.13 \\
\hline Radix ovatalperegra & 327.7 & 462.9 & 2.76 & 1.17 & 3.93 & 65.07 \\
\hline Caenis spp. & 4.9 & 195.5 & 2.17 & 2.32 & 3.08 & 68.15 \\
\hline Goera pilosa & 6.1 & 158.8 & 1.93 & 1.34 & 2.74 & 70.89 \\
\hline Polycentropus flavomaculatus & 10.1 & 146.8 & 1.86 & 1.90 & 2.65 & 73.54 \\
\hline Orthocladiinae & 239.4 & 152.5 & 1.57 & 1.27 & 2.23 & 75.78 \\
\hline \multicolumn{7}{|l|}{ Groups 0 and 7} \\
\hline \multicolumn{7}{|l|}{ Average dissimilarity $\quad 73.53$} \\
\hline Dreissena polymorpha & 5928.2 & 77378.6 & 38.09 & 2.08 & 51.81 & 51.81 \\
\hline Radix ovatalperegra & 327.7 & 1081.4 & 4.67 & 1.37 & 6.35 & 58.16 \\
\hline Pisidium spp. & 8.1 & 419.1 & 3.52 & 2.16 & 4.78 & 62.94 \\
\hline Chironominae & 43.5 & 342.9 & 2.72 & 1.41 & 3.70 & 66.64 \\
\hline Gammarus roeseli & 416.1 & 40.2 & 2.48 & 1.09 & 3.38 & 70.02 \\
\hline Bithynia tentaculata & 137.6 & 153.2 & 2.05 & 1.26 & 2.79 & 72.81 \\
\hline Orthocladiinae & 239.4 & 9.1 & 1.86 & 1.08 & 2.53 & 75.35 \\
\hline
\end{tabular}

Cut off at $75 \%$. SD: standard deviation; LWL: low water level

\section{Discussion}

Species patterns

The neozoon Dreissena polymorpha dominated the invertebrate fauna and was the most important species in the sample ordinations with regard to both abundance and biomass, although the data were square root transformed to downplay the role of this dominant species. Dreissena polymorpha, when present, is also the dominant species in Danish lakes (Brodersen et al., 1998). Dreissena polymorpha was first recorded in Lake Constance in 1965 (Siessegger, 1969) and since then has become distributed throughout the lake. The seasonal dynamics of Dreissena polymorpha is regulated by settlement of the larvae in summer and subsequent somatic growth (Wacker \& von Elert, 2003) and predation by waterfowl, which induces a decrease in abundance and biomass in winter (Werner et al., 2005). Apparently, the eulittoral zone is colonised each year by recruits of deeper settling mussels. The lack of mobility, particularly of the larger mussels, makes it unlikely for the zebra mussel to respond to the water-level fluctuations in the eulittoral zone with appropriate depth movements (Toomey et al., 2002).

The high abundance and small biomass of Dreissena polymorpha at the drift line illustrate the lack of older individuals in the eulittoral zone owing to predation and water-level fluctuations.

Nymphs of the mayfly Ecdyonurus dispar and of the stonefly Leuctra sp. occurred only in the eulittoral samples in June. The presence of early instars of these taxa in the interstitial can be a competitive advantage when the water level rises and covers the formerly dry eulittoral habitats because larvae from the interstitial can settle promptly. Short-term variations in species arrival can influence the outcome of 
interspecific interactions (Morin, 1999). Hence, the seasonal water-level fluctuations seem to facilitate the occurrence of these species.

\section{Community patterns}

The epibenthic macroinvertebrate community at the sampling site exhibited a gradual transition in the community structure with water depth. Like a distance map, the NMDS plots illustrate the littoral zone with the infralittoral zone on the left side and the eulittoral zone on the right side of the plot. The stress value for all configurations is, particularly considering the large sample number, sufficiently low to view the two-dimensional plot as a useful representation of the multidimensional picture. Pronounced similarities of samples within a depth zone and differences between adjacent zones support the hypothesis that water depth is a key factor in structuring the littoral macroinvertebrate community.

With regard to depth, the largest differences in the community structure occurred between drift-line samples and the other samples, and the variation was largest within the drift-line samples. Here, the extent of variation was not only caused by the differences in season, but was also correlated with water-level fluctuations prior to the sampling. Although the course of the water level has a basic seasonal pattern, season and water-level fluctuations are not necessarily correlated because of variations from year to year (Fig. 7). The colonisation of the drift-line habitat during sinking water levels differs from that during rising water levels, and the macroinvertebrate assemblage depends partly on the duration of the flooding of the habitat. This is probably connected with the availability of food resources for non-predatory invertebrates, e.g. the lack of epilithic algae at the drift line when the water level is rising or the presence or absence of allochthonous coarse particulate organic matter (CPOM).

Abiotic disturbances are strong and frequent in the eulittoral zone: The sheer stress caused by wave action is higher in the eulittoral zone and leads repeatedly to extensive movements of the substrate, depending on wind exposure. Water-level fluctuations create and destroy new habitats, facilitating pioneer species (Hofmann et al., 2008).

Although the invertebrate data were square-root transformed to downplay the influence of the most abundant species and the species with the highest biomass, differences and grouping in the ordination were influenced more by changes in the dominance structure than by an exchange of species. This indicated that different zonation is not merely due to different physiological capabilities of a species, but is also the result of competition and predation effects (Connell, 1961).

The difference between autumn 1999 and 2000 is probably the consequence of the exceptionally high gauging level that had occurred in June 1999. Owing to the high water level, the available settlement area for invertebrates in the eulittoral zone was increased dramatically. Unusually high abundances correlated with a large settlement area support the hypothesis that space is a limited resource in the littoral zone, at least for some invertebrates (Quinn et al., 1998), e.g. the zebra mussel Dreissena polymorpha, which had an extremely high abundance and biomass in September and December 1999 following the high water level compared to in the same months of 2000.

There is evidence that global climate change leads to increasing rainfall on the northern sides of the Alps and in the same time temperature rises and therefore snowmelt is shifted to earlier periods. Both effects in combination lead to the assumption, that the occurrence of extreme flood peaks in Lake Constance will be earlier in future (Joehnk et al., 2004). This shift in the occurrence time of flood peaks may change the dominance structure in the macroinvertebrate community of the eulittoral zone. Juveniles of Dreissena polymorpha and associated species may have advantages, while it is unclear how pioneer species with early instars in the interstitial of the dry eulittoral zone such as the stonefly Leuctra sp. will respond.

The water-level fluctuations have become a special feature of Lake Constance, which is the only large pre-alpine lake that is not subject to extensive regulation of the water level and therefore has a distinctive eulittoral zone. A detailed comparison of the community with those of the stony littoral zone of other pre-alpine lakes would be of interest, particularly with regard to the importance of the dynamically flooded eulittoral zone for pioneer species, which could have implications for nature conservation measures.

Acknowledgements We thank C. Fiek, the members of the scientific diving group of the Limnological Institute of the 
University of Konstanz (P. Fischer, O. Walenciak, T. Jankowski, M. Wolf, E. Gross and K. Pohlmann), and H. Goldschmidt, S. Röck, C. Kienle, M. Korn, and C. Danzer for assistance in the field and in the laboratory. Many thanks to Karen Brune for editing the English and to Eva Leu and Karl Matthias Wantzen for comments on an earlier version of the manuscript. This study was supported by the DFG within the collaborative research centre 454 "Lake Constance Littoral".

\section{References}

Bailey, R. C., K. E. Day, R. H. Norris \& T. B. Reynoldson, 1995. Macroinvertebrate community structure and sedi ment bioassay results from nearshore areas of North American Great Lakes. Journal of Great Lakes Research 21: 4252.

Baumgärtner, D., 2004. Principles of Macroinvertebrate Community Structure in the Littoral Zone of Lake Con stance. Verlag Regionalkultur, Heidelberg.

Baumgärtner, D. \& K. O. Rothhaupt, 2003. Predictive length dry mass regressions for freshwater invertebrates in a pre alpine lake littoral. International Review of Hydrobiology 88: 453463.

Brodersen, K. P., P. C. Dall \& C. Lindegaard, 1998. The fauna in the upper stony littoral of Danish lakes: macroinver tebrates as trophic indicators. Freshwater Biology 39: 577592.

Chapman, M. G. \& A. J. Underwood, 1999. Ecological patterns in multivariate assemblages: information and interpreta tion of negative values in ANOSIM tests. Marine Ecology Progress Series 180: 257265.

Clarke, K. R., 1993. Non parametric multivariate analyses of changes in community structure. Australian Journal of Ecology 18: 117143 .

Clarke, K. R. \& M. Ainsworth, 1993. A method of linking multivariate community structure to environmental vari ables. Marine Ecology Progress Series 92: 205219.

Clarke, K. R. \& R. H. Green, 1988. Statistical design and analysis for a "biological effects" study. Marine Ecology Progress Series 46: 213226.

Cobb, S. E. \& M. C. Watzin, 1998. Trophic interactions between yellow perch (Perca flavescens) and their benthic prey in a littoral zone community. Canadian Journal of Fisheries and Aquatic Sciences 55: 2836.

Connell, J. H., 1961. The influence of interspecific competition and other factors on the distribution of the barnacle Chthamalus stellatus. Ecology 42: 710723.

Dall, P. C., C. Lindegaard, E. Jonsson, G. Jonsson \& P. M. Jonsson, 1984. Invertebrate communities and their environment in the exposed littoral zone of Lake Esrom, Denmark. Archiv für Hydrobiologie Supplement 69: 477524.

Death, R. G., 1995. Spatial patterns in benthic invertebrate community structure: products of habitat stability or are they habitat specific? Freshwater Biology 33: 455467.

Diehl, S., 1992. Fish predation an benthic community struc ture the role of omnivory and habitat complexity. Ecology 73: 16461661.
Ehrenberg, H., 1957. Die Steinfauna der Brandungsufer ostholsteinischer Seen. Archiv für Hydrobiologie 53: 87159.

Fischer, P. \& R. Eckmann, 1997. Spatial distribution of littoral fish species in a large European lake, Lake Constance, Germany. Archiv für Hydrobiologie 140: 91116.

Gilinsky, E., 1984. The role of fish predation and spatial het erogeneity in determining benthic community structure. Ecology 65: 455468.

Harrison, S. S. C. \& A. G. Hildrew, 1998a. Patterns in the epilithic community of a lake littoral. Freshwater Biology 39: 477492.

Harrison, S. S. C. \& A. G. Hildrew, 1998b. Distribution dynamics of epilithic insects in a lake littoral. Archiv für Hydrobiologie: 143: 275293.

Harrison, S. S. C. \& A. G. Hildrew, 2001. Epilithic commu nities and habitat heterogeneity in a lake littoral. Journal of Animal Ecology 70: 692707.

Hayne, D. W. \& R. C. Ball, 1956. Benthic productivity as influenced by fish predation. Limnology and Oceanogra phy 1: 162175 .

Hofmann, H., A. Lorke \& F. Peeters, 2008. Temporal scales of water level fluctuations in lakes and their ecological implications. Hydrobiologia. doi:10.1007/s10750 008 94741.

Internationale Gewässerschutzkommission für den Bodensee (IGKB), 1994. Limnologischer Zustand des Bodensees. Jahresbericht der Internationalen Gewässerschutzkom mission Bodensee 9.

Jackson, D. A. \& H. H. Harvey, 1993. Fish and benthic invertebrates: community concordance and community environment relationships. Canadian Journal of Fisheries and Aquatic Sciences 50: 26412651.

Joehnk, K. D., D. Straile \& W. Ostendorp, 2004. Water level variability and trends in Lake Constance in the light of the 1999 centennial flood. Limnologica 34: 1521.

Johnson, D. M., T. H. Martin, P. H. Crowley \& L. B. Crowder, 1996. Link strength in lake littoral food webs: net effects of small sunfish and larval dragonflies. Journal of the North American Benthological Society 15: 271288.

Johnson, R. K., 1998. Spatiotemporal variability of temperate lake macroinvertebrate communities: detection of impact. Ecological Applications 8: 6170.

Johnson, R. K. \& W. Goedkoop, 2002. Littoral macroinverte brate communities: spatial scale and ecological relationships. Freshwater Biology 47: 18401854.

Kruskal, J. B. \& M. Wish, 1978. Multidimensional Scaling. Sage Publications, Beverly Hills, CA.

Macan, T. T., 1966. The influence of predation on the fauna of a moorland fishpond. Archiv für Hydrobiologie 61: 432 452.

Morin, P. J., 1999. Community Ecology. Blackwell Science.

Muckle, R., 1942. Beiträge zur Kenntnis der Uferfauna des Bodensees. Beiträge zur naturkundlichen Forschung im Oberrheingebiet 7: 1109.

Quinn, G. P., P. S. Lake \& E. S. G. Schreiber, 1998. A com parative study of colonization by benthos in a lake and its outflowing stream. Freshwater Biology 39: 623635.

Reid, R. A., K. M. Somers \& S. M. David, 1995. Spatial and temporal variation in littoral zone benthic invertebrates 
from three south central Ontario lakes. Canadian Journal of Fisheries and Aquatic Sciences 52: 14061420.

Siessegger, B., 1969. Vorkommen und Verbreitung von Dre issena polymorpha Pallas im Bodensee. Wasser Abwasser 110: 814815 .

Tolonen, K. T., H. Hämäläinen, I. J. Holopainen \& J. Karja lainen, 2001. Influences of habitat type and environmental variables on littoral macroinvertebrate communities in a large lake system. Archiv für Hydrobiologie 152: 3967.

Toomey, M. B., D. McCabe \& J. E. Marsden, 2002. Factors affecting the movement of adult zebra mussels (Dreissena polymorpha). Journal of the North American Bentholog ical Society 21: 468475.

Wacker, A. \& E. von Elert, 2003. Settlement pattern of the zebra mussel, Dreissena polymorpha, as a function of depth in Lake Constance. Archiv für Hydrobiologie 58: 289301.
Werner, S., M. Mörtl, H. G. Bauer \& K. O. Rothhaupt, 2005. Strong impact of wintering waterbirds on zebra mussel (Dreissena polymorpha) populations at Lake Constance, Germany. Freshwater Biology 50: 14121426.

Wesenberg Lund, C., 1908. Die littoralen Tiergesellschaften unserer größerer Seen. Internationale Revue der Gesamten Hydrobiologie 1: 574609.

Winnell, M. H. \& D. J. Jude, 1987. Benthic community structure and composition among rocky habitats in the Great Lakes and Keuka Lake, New York, USA, Canada. Journal of Great Lakes Research 13: 317.

Wong, A. H. K., D. D. Williams, D. J. McQueen, E. Demers \& C. W. Ramcharan, 1998. Macroinvertebrate abundance in two lakes with contrasting fish communities. Archiv für Hydrobiologie 141: 283302. 